[This version of the paper has been accepted for publication in Organization Studies on 25 August 2018]

\title{
Whistleblower subjectivities: organization and passionate attachment
}

\begin{abstract}
What is the nature of whistleblower subjectivity? In this article, we depart from current scholarly depictions of this figure as a fearless truth-teller who is fully independent of the organization. We argue for a new framing that sees the selfconstruction of the whistleblower as infused with passionate attachments to organizational and professional norms, even after one experiences severe reprisals. We base our claims on recently-gathered empirical data and draw on Judith Butler to theorize how, contrary to existing understandings, passionate attachments to one's organization and profession shape whistleblower subjectivity, rather than conscious risk-taking, or autonomous self-reinvention. Our second contribution is to highlight the importance of practical and material supports for this vital figure in society; until now the whistleblower has been idealized as an extraordinary hero rather than a real human in need of assistance. Overall, we propose a new theorization of the whistleblower involving passionate investments in the organization or profession that has cast one out.
\end{abstract}


Key words: affective attachments, Butler, Foucault, parrhesia, psychosocial, subjectivity, whistleblower

\section{Introduction}

Whistleblowing is most frequently described as an employee's 'disclosure of illegal, immoral, or illegitimate practices under the control of their employers to persons or organizations that may be able to effect action' (Miceli, Near \& Dworkin, 2008, p. 6), for others it is an act of 'speaking truth to power' (Munro, 2017). In a world in which wrongdoing is rife within public and private organizations, whistleblowers have exposed financial fraud, public health threats, and dangerous working conditions. Yet little is known about whistleblowers themselves and how they make sense of their positions (Contu, 2014; de George, 2010). Instead, stereotypes abound; whistleblowers are regarded as heroes and saints by some, and as traitors and villains by others (Grant, 2002; Hersch, 2002). Given this lacuna, and the ambivalence with which this vital figure is often perceived, new approaches both theoretical and practical are essential.

Studies of organizational whistleblowing typically adopt a quantitative, positivist approach to 'profiling' whistleblowing, attempting for example to understand the variables that will lead to greater likelihood of people speaking out, achieving impact, or suffering reprisal (Martin \& Rifkin 2004; Miceli et al., 2008). This article addresses another, smaller stream of research that aims to understand the subjectivity of the whistleblower and typically adopts a Foucauldian perspective to do so (Alford, 2001). 
The idea is that the whistleblower subject is constructed amid a network of historical, cultural and institutional discourses (Perry, 1998). Recently scholars have drawn on Foucault's reading of the concept of parrhesia -- fearless speech -- from Ancient Greece (Foucault, 2010; see also Vandekerckhove \& Langenberg, 2012), to understand whistleblowing as one such instance. The subjectivity of the whistleblower emerges through the process of speaking freely to articulate one's truth, even where this means challenging those more powerful than oneself. What tends to be overlooked is the question of how whistleblower subjectivity is formed and how attachments shape this process; instead whistleblower subjectivity is depicted as being founded upon a deliberate decision to risk one's own livelihood through a singular action emerging from one's own desire, that is, as free of attachments.

In this article, we interrogate this position. Our goal is to examine in-depth the shaping of the whistleblower's subjectivity, the positions adopted and the role of the organization. As others note, the whistleblower is not a pre-existing entity but rather emerges as an ethical subject through the practice of speaking out (Weiskopf \& Willmott, 2013). We develop this idea further to show that one's construction of oneself as whistleblower is not merely bound up in the specific discursive and circumstantial context but that it is an affective phenomenon inscribed by the employee's passionate attachment to organizational ideals and professional norms. We draw our inspiration from Judith Butler's work to offer novel theoretical contributions on speaking up in organizations. Our contributions are primarily to literature on whistleblowing and secondarily to debates on parrhesia within this. Specifically, we illuminate constructions of whistleblower subjectivity as these take place during 
interview interactions, showing that these are structured neither around risk-taking, nor a free and independent reinvention of self, but are founded on passionate investments in organizational and professional ideals. This suggests a new way to theorize organizational whistleblowing that encompasses affective identifications with the very organizations and professions that have excluded the discloser.

The article proceeds with an overview of relevant literature on organizational whistleblowing before describing in-depth our methodological approach. This is followed by detailed description and analysis of whistleblowers' accounts, and a discussion of how these relate to existing literature. We conclude by developing an alternative conception of the organizational whistleblower and detail the emerging theoretical and practical implications.

\section{Whistleblowing subjects}

How are whistleblower subjectivities currently understood? In Alford's (2001) influential work, whistleblowers' accounts of themselves depict resistant subjects, each spurred into action by a personal and irresistible drive to correct a perceived wrongdoing. Similarly drawing on Foucault, and building on Alford's ideas, recent organizational scholarship views the whistleblower subject as constituted through a process of parrhesiastic truth-telling (Andrade, 2015; Jack, 2004; Contu, 2014; Mansbach, 2009; Rothschild, 2013; Vandekerckhove \& Langenberg, 2012; Vandekerckhove, 2006; Weiskopf \& Tobias-Miersch, 2016). This involves articulating the plain truth as one sees it because of a specific 'relation to truth through frankness' 
and 'moral law through freedom and duty', which one holds (Foucault, 2001, p. 19; 2005, see also Jones, Parker \& ten Bos, 2005; Mansbach, 2009; Rothschild, 2013). The whistleblower is positioned as a subject morally obliged to act, by for example speaking out against organizational wrongdoing (Jack, 2004, p. 130; Weiskopf \& Tobias-Miersch, 2016, p. 652). This positioning as parrhesiastes enables one to reject 'the security of a life where the truth goes unspoken'; instead the whistleblower forges a relation to himself as a truth-teller through a "pact... with himself' (Mansbach, 2009; Weiskopf \& Tobias-Miersch, 2016, p. 658). Constructing oneself in this way is part of the "ethico-political practice that opens up possibilities of new ways of relating to the self and others (the ethical dimension) and new ways of organizing relations to others (the political dimension)' that whistleblowing-asparrhesia involves (Weiskopf \& Tobias-Miersch, 2016, p. 650). Parrhesia thus offers a useful way of positioning oneself and one's actions, as whistleblower.

This perception of whistleblowing subjectivity is compelling because it offers an alternative to other, more ambiguous and at times disparaging, depictions of whistleblowers (Andrade, 2015; Jones, Parker \& ten Bos, 2005; Mansbach, 2009). In place of this contradictory identity, where whistleblowers are seen both as heroes and traitors, the parrhesiastic whistleblower subject is based on 'an act of integrity' (Rothschild, 2013, p. 656). Such a framing also sees the whistleblowing subject as political because they have engaged in speaking truth from a relatively powerless position in order to disrupt the status quo and effect change (Contu, 2014; Mansbach, 2009; Weiskopf \& Tobias-Miersch, 2016, p. 650), as Weiskopf and Willmott (2013) show in their discussion of Daniel Ellsberg's attempts to speak out 
about the U.S. government's involvement in the Vietnam war. Finally, risk is an important aspect of this framing (Contu, 2014; Mansbach, 2009; Rothschild, 2013). Whistleblower subjectivity is depicted as involving full awareness of the dangers of speaking out for one's wellbeing (Andrade, 2015; Jack, 2004; Mansbach, 2011; Weiskopf \& Tobias-Miersch, 2016; Weiskopf \& Willmott, 2013, p. 483), and speaking up regardless (Foucault, 2001, p.19; Foucault, 2010). These risks emerge from the type of criticism typical of parrhesiastic challenge: a relatively weak actor speaking truth to a more powerful one.

Yet these theorizations raise questions about the precise role of the organization in the self-constitution of organizational whistleblower-parrhesiastes. Despite having received scant attention in the literature to date, some ideas emerge. First, discourses of professionalism can influence. Drawing on Foucault, Weiskopf and Tobias-Miersch (2016) for example show how organizational whistleblowers make use of methods of 'tekhne': formal rules and obligations, by describing how well-known discloser Guido Strack drew on 'expert knowledge' of the often contradictory discursive frames of bureaucracy and economics, when he critiqued the European Union for 'wasting taxpayer money' (ibid., p. 661). The subject position that enabled him to continue was one of 'legal professional' as well as that of a truth-teller (see also Mansbach, 2009). Observing this, the authors call for further work on the ways in which organizations influence whistleblowing-as-parrhesia (Weiskopf \& Tobias-Miersch, 2016, p. 652).

A second idea implies that the construction of whistleblower subjectivity is premised upon a radical break from the organization and an apparent re-invention of the self 
(Mansbach, 2009, Weiskopf \& Tobias-Miersch, 2016, p. 658). Mansbach (2011) for example describes the 're-identification that [organizational] whistleblowers undergo as they travel through the process of the disclosure, from its initial uncertainties and subsequent upshot to the re-appropriation of speech that the act of whistleblowing enables' (ibid., p. 12). Yet existing interpretations remain vague on the precise nature of this 're-identification', specifically in relation to the freedom or otherwise of the truth-telling subject. Thus, for Weiskopf and Tobias-Miersch, Guido Strack speaks freely in his 'own name' (2016, p. 656) and in doing so, adopts a position of truthteller that breaks from the discursive frames that surround him. He constitutes himself as an ethical subject who, through a pact with himself, "voluntarily follow[s] his personal sense of moral duty' (Weiskopf \& Tobias-Miersch, 2016, p. 658). Contu draws upon the Lacanian concept of 'pure desire' to understand whistleblower subjectivity as premised on a 'singular' act that is free from symbolic authority (2014, p. 399; see also Mansbach, 2009). This echoes other analyses in which freedom is emphasized; for Grant (2002), the subject of whistleblower evokes a 'singlemindedness through which the issue is posed with such crystal clarity... that there is no question abut what must be done... They are different' (p. 398). Meanwhile Alford (2001, p.76) describes those he studies as 'true individuals'. Under this view, whistleblower subjectivity is marked by a position of freedom. The subject is positioned as unattached, unencumbered by social constraints including those relating to one's organization.

Under this view whistleblower subjectivity is founded on a radical break from the organization that has previously dominated, and in many cases retaliated against one. 
A sense of distance from the corrupt former employer is evoked, alongside: 'a magnified sense of their own integrity [and] a new political identity' (Rothschild, 2013, p. 647, see also Weiskopf \& Willmott, 2013, p. 471). In summary, while the construction of whistleblower subjectivity is understood to be shaped by social norms, it is predominantly seen as evoking a position of freedom including a radical break from the whistleblower's organization. Yet such approaches disregard attachments to one's organization and how whistleblowers conceive of themselves as defenders of professional norms, as this article will demonstrate.

Scholars who make these claims on behalf of organizational whistleblowers typically draw on secondary accounts of famous truth-tellers, or abstract theorizing that is rarely based on empirical work. While this is understandable because of the inevitable difficulty in researching whistleblowing 'in practice', it is nonetheless surprising because as with parrhesia, whistleblowing is, at its core, an 'everyday embodied practice' (Jack, 2004, pp. 1221-34). In contrast, drawing on recently-gathered empirical studies allows us to interrogate the constitution of subjectivity on the part of whistleblowers, and to respond to recent calls for developing a more nuanced conception (Contu, 2014; Weiskopf \& Tobias-Miersch, 2016). Specifically, we develop and expand our understanding of whistleblower subjectivity, finding it to be deeply embedded in organizational attachments that are not easy to shake off, and we find Judith Butler's concept of passionate attachment to be helpful in theorizing this. 


\section{Theoretical framework}

Judith Butler's project valuably takes forward Foucault's concept of subjectivity as constituted within, and constituting, discourse (Hall, 2000, p. 28), and therefore is appropriate in this context. In exploring the dynamics by which subjects are positioned amid discourse and asking what happens in the moment of subjection, she draws upon Hegelian philosophy and the psychoanalytic ideas of Jacques Lacan to develop a theory of subjectivity. Psychic processes of desire lead to identifications with given social norms (Butler, 1997), which are both suffused with affect, and allow us to be recognized as a legitimate subject. Inspired by Lacan's idea of psychic development as a continuous search for unattainable unity by the human subject (Fotaki, 2010, 2009), she describes how people striving to overcome a felt alienation subjectify themselves to the norms, laws, rituals and language governing their social world ('the symbolic order'), in order to acquire an illusory sense of stable identity.

For Butler, we have no choice but to seek recognition in this manner, through discourse but also through affective attachments to norms and values, because we require recognition to exist socially, that is, to occupy a stable place within the symbolic order. The subject 'responds to reflections of itself in emotional ways, according to whether that reflection signifies a diminution or augmentation of its own possibility of future persistence and life' (Butler, 2004, p. 235). 'Passion and grief and rage' mark our experiences of being torn from ourselves and bound to others, and this 'implicate(s) us in lives that are not our own, sometimes fatally, irreversibly' (ibid., p. 20). We depend on the others we encounter for the normative recognition we so desire 
(Butler, 2004; see Kenny, 2010, 2017; Riach, Rumens \& Tyler, 2014 for organizational examples): although the symbolic order is the domain of language, the ability to confer recognition lies with the diffuse network of others, whose ongoing practices of subjection maintain it in place. This dependency, or interdependency, expresses itself as attachments that are experienced as affective, or 'passionate'.

Butler thus extends Foucault's work on discursive power by describing such desiredriven affective attachments to others as the bearers of this order. Failure to attain recognition can be experienced as hurtful or even catastrophic for one's sense of self. If we cannot be recognized as legitimate human beings in the terms offered to us by such symbolic norms, or if we fall outside of these, then 'we are not possible beings; we have been foreclosed from possibility' (Butler, 2004, p. 31). This plunges us into an existential crisis, and we therefore work hard to avoid this situation, sometimes adhering to subject positions that hurt us (Butler, 1990).

Theories emphasizing emotions are frequently critiqued from a poststructuralist, Foucauldian standpoint because they focus on the sovereign autonomous self who 'feels', rather than the individual subject's location amid discourses of power, but this is not the case here. Rather, Butler's affects are distinguished from emotions and relate to unconscious psychic dynamics of the body's desire to be (KomporozosAthanasiou, Thompson \& Fotaki; Fotaki, Kenny \& Vachhani, 2017). They are expressed as the 'force' that fuels the 'form' of subjective attachment to discourse (Kenny \& Gilmore, 2014, p. 166; Parker, 2005; Hook, 2007). Such insights enrich Foucault's work on subjectification to power, which tends to actively downplay and in 
some cases, ignore issues of passion and emotion (Jameson, 1984). Butler's work illuminates how affective forces contribute to the reproduction of discursive norms and how individual subjectivities are thereby constituted. These ideas help us to make sense of the empirical data we gathered on whistleblower subjectivities and how, for example, they are shaped by organizational and professional norms that appear to persist against all odds, concomitantly causing pain even as they engender attachment.

\section{Methods}

\section{Data collection}

All three researchers have experience in in-depth studies of whistleblowing. Our study draws upon thirty unique cases of whistleblowing in a variety of sectors, originating from two different research projects carried out by the first and second authors jointly and individually over a period of five years (Table 1). Both projects had adopted a qualitative and interpretive approach, used a similar interview protocol, and focused on issues of whistleblower subjectivity. We combined the two projects as others have done (Reay et al., 2013), because of the similarities therein. All participants had engaged in whistleblowing: attempting to speak out about misconduct in their organization and trying to compel senior colleagues to act. All had experienced retaliation of various kinds from within their organizations and began to see themselves and be seen by others as 'whistleblowers' (Rothschild, 2013). Study 1 comprised fifteen incidents of speaking out in the financial sector across Europe and the U.S. (author 1), while study 2 examined what makes whistleblowing possible in various industries and across countries involving a sample of twenty two (Study 2, 
authors 1 and 2), seven of whom were drawn from Study 1 and interviewed a second time. Most participants were selected initially through contacts in whistleblower advocacy groups. Where participants were interviewed a second time (Table 1), author 2 carried out the research to gain additional insights into their stories. Author 3's extensive experience in researching whistleblowing and specific knowledge of parrhesiastic whistleblowing further enhanced analysis and interpretation.

For each study, secondary information had been gathered on participants' cases including newspaper stories, organizational documents and publicly-available hearing transcripts where relevant, prior to meeting them. People's claims had been verified with other whistleblowers, advocacy groups and by checking documentation. Interviews focused on experiences of whistleblowing and its aftermath and typically lasted between 1 and 3 hours. Adhering to our institutions' ethical protocols, we were prepared to offer advice on sources of help should participants become distressed.

\section{Producing analysis}

Coming together as a team, our analytic strategy broadly followed the constructivist interpretation of grounded theory in which theories are constructed through the 'past and present involvements' of the researchers with 'people, perspectives and practices' (Charmaz, 2006, p. 9). Following Charmaz, this was complemented by

other approaches inspired by our chosen poststructuralist and psychoanalytic 
framework. Analysis involved a series of iterative and non-linear phases. Reading and re-reading the data, each researcher produced extended memo notes, iterating between data and theory to develop ideas (Alvesson \& Sköldberg, 2009). Our focus was on an emergent concept: that of shifting subjectivities on the part of our whistleblower interviewees. This had not been developed in-depth in existing work on whistleblowing much of which draws upon secondary accounts. Coming together to discuss this, we noted that in each case, people self-identified as whistleblowers but that this was a complex position. Inspired by scholars who adopt similar approaches to the constitution of subjectivity in organizations (Driver, 2012), in further analyzing the data we paid attention to the ways in which people positioned themselves in relation to wider discourses, and specifically to how they represented their selves, or the "I" (Harding, 2008), amid sometimes shifting norms and discourses, to validate their existence (Parker, 2005). Recognizing the centrality of paradox for psychoanalytically-informed methodologies, we were attentive to emergent findings that appeared contradictory initially, highlighting these for discussion. This was important for countering the tendency within academic research to strive for false coherence that is artificially imposed (Parker, 2005; see also Driver, 2012; Hook, 2007).

Based on this and our overarching research question, the initial stage of analysis involved identifying issues that appeared significant for participants in relation to how they linguistically constructed themselves as whistleblower subjects. We then compared initial categories across our cases. This involved re-reading the material and systematically labelling chunks of text for first level coding. Codes included terms 
such as 'loyalty', 'trust', 'values' and 'professionalism'. Bringing together similar accounts, we highlighted aspects such as 'surprise upon discovery of the wrongdoing', 'fear of falling out with colleagues', 'protecting the reputation of the profession', 'organizational retaliation', 'being excluded', and 'becoming a whistleblower'. We reviewed the codes as we progressed and checked for overlaps, merging codes or developing new ones. In the end this process yielded five primary themes as illustrated in Table 2. We then re-analyzed our findings in light of the organizational literature on whistleblowing and turned to theoretical frameworks on the psychosocial formation of subjectivity in organizational contexts. People's accounts of what we understood to be their subjectivity in relation to whistleblowing were complex, but appeared to involve self-positioning as loyal employees and committed professionals who performed their statutory duty, rather than as fearless parrhesiastes. Subjectivities appeared to be intertwined with recognition from the organization, colleagues and the profession, even as people posited themselves as victims of retaliation. Exploring this further yielded sub-themes within each of our primary categories, for example it emerged that 'professionalism' consisted of an adherence to professional rules, a sense of traditional values, and an awareness of one's own contribution to the professional community. At this point. given the significance of individuals' relations to their organizations, we further refined our primary themes to reflect the subject positions apparently adopted by people to include (i) professional subject; (ii) outsider; (iii) loyal employee and (iv) involuntary discloser (see Table 2 for examples). This allowed us to proceed with our theoretical development in relation to the question of how organizational whistleblower subjectivities are constructed, post-disclosure. The process proceeded through mutual 
discussion and consideration, feedback from presentation at an academic workshop, and inductive tacking back and forth (Charmaz, 2006) between literature on parrhesia in organizations and relevant psychosocial and poststructuralist theories including Butler's theory of affective recognition through symbolic discourses and other subjects (Butler, 1997), to explain the apparent influence of organizational norms rather than self-constructions as free and heroic individuals.

As researchers, we acknowledge that we are each caught up in relations of power involving many disparate aspects of our lives and work (Fotaki \& Harding, 2013; Gilmore \& Kenny, 2015; Pullen, 2006), including notions of authorial authority, as we present and dissect experiences of other people (Parker, 2005). In response, we attempt to avoid fixing our participants into particular categories (Riach, Rumens \& Tyler, 2016), through for example including people in developing research interpretations (Ellis, 2007), at stakeholder workshops in Belfast, Northern Ireland (January 2015) and London, UK (June, 2015). In addition, we acknowledge that research interviews are necessarily performative interactions (Butler, 1990), in which the subject positions of both researcher and researched are constituted. For example, in contacting people for interview we are implicitly contributing to their adoption of the subject position 'whistleblower', a position into which they had already been placed by advocacy groups, the media and other parties; we sought them out and asked them to once again speak from this place. This has effects and rather than ignore these, we instead take it as a starting point that shapes our analysis. We therefore study the complex and multi-faceted ways in which such a proffered subject 
position is constructed by both participant and researcher in interaction with each other.

When called upon to do so, whistleblowers drew on a variety of discursive subject positions. These naturally included positions that did not relate to their organization including as family member, person of religious faith, and citizen. These are outside the scope of our research focus, but are explored elsewhere in depth (Kenny, Fotaki \& Scriver, 2018; Kenny, 2017).

\section{Constructing the whistleblower subject}

We were interested in how people's subjectivities were shaped by their experiences of speaking up in their organizations, the role of the organization in this, and specifically how these accounts emerged in the interview setting. We found that a variety of positions were invoked, ranging from loyal organizational subject, to involuntary, compelled discloser. Our interviewees tended to describe moving back and forth between subject positions. These were by no means homogeneous: discursive strategies of course differed across participants. However, certain tendencies appear to be shared. We are limited in the space available for presenting this rich data and so we provide indicative excerpts in what follows, with further examples given in Table 2.

It is interesting that people's self-articulations rarely included the label 'whistleblower'; respondents appeared only to identify with this term after some time had passed since their disclosure and subsequent struggle with the organization, and even then, only when they had been called 'whistleblower' by other parties including 
journalists and authors. Even so, all those interviewed accepted this label, selfidentifying as such.

\section{Professional}

People frequently articulated themselves as having been committed to the ideals of the profession in which they worked, a commitment that prompted them to act when wrongdoing they perceived threatened this. This position of professional comprised a number of features: first was a strong attachment to the profession itself and the rules and regulations that govern it. Lauren for example had been an executive vicepresident overseeing fraud investigation at a large U.S. mortgage bank. Fraud was widespread across the organization, and when she spoke up about fake documents being used to grant customer mortgages, she was dismissed. In response to questions about her work at the bank, she described loving her profession, even as she makes fun of her own passion for it:

I accepted the position because fraud was my love... fighting fraud was something I loved to do (laughs).

Ted, who had been director of the UK company contracted to complete a $£ 2$ billion military telecommunication project for Saudi Arabia's National Guard on behalf of the UK Ministry of Defence, described his assignment as a dream job. In the interview, he explained that it was: 'Not only the challenge of the job' that attracted him to it, but rather: 
[...] everything that it asked for I had seemingly been trained for ... I understood all about military communications because I'd been doing it in the army for 23 years.

Previously a respected army officer (a retired colonel-lieutenant) and experienced project manager, he realized after some months in the role that he was being asked to sign off fraudulent contracts. He refused and reported the case to the Ministry of Defence, and after this was singled out and punished. For both Ted and Lauren, this position of professional was described as contributing to a sense of incredulity upon discovering the fraud that was taking place in their very different organizations. Realizing that 'every employee in the place just about was doing it [engaged in mortgage fraud]', Lauren said she was:

shocked beyond belief ... You'd think that the correct behavior for a regional manager would be to be aligning with the corporate fraud group, to say, 'hey, if there are employees in my region committing fraud, I need to know about it.' Not going out and warning his employees and saying 'hey, they are onto us!' (laughs a little)

Ted espoused similar astonishment at his betrayal by the very institution he trusted the most. He described his earlier faith in the Ministry of Defence's willingness to listen, which prompted him to speak up, and his shock that this was entirely misplaced. Even having been through what he perceived to be unfair reprisals for merely speaking out about corruption in the organization he loved, he nonetheless positioned himself as an old-fashioned 'military man'. Despite his betrayal by the military, Ted holds strongly to its values: 
I come from a military background. Okay. The reason people fight in a trench on the battlefield is because I protect you and you protect me and we have a common understanding about 'I will not betray you; I will not run away; I will stand and look after you; and you will do the same for me.' ... Beneath that is an understanding of trust. ... And when you betray that trust you undermine the whole structure of society.

In describing 'who they were', others articulated their positions as comprising a strong commitment to the old, traditional ideals of their profession (Table 2), even where these ideals had been seriously compromised by the corruption they witnessed.

Finally, some whistleblowers portrayed their current absence from their profession, having been blacklisted for speaking out, as a significant loss to the profession itself. As Edward, a very senior executive at a US bank who spoke up about mistreatment of his colleagues through risks to their health and safety, along with a toxic sales culture that encouraged customers to purchase mortgages they could not repay, noted:

How is it that I who did everything right for the entirety of my career-how am I unemployable when I was so eminently employable? How could [my whistleblowing] be regarded as a bad thing? I still don't get it. .... Especially because I'm about to be an empty-nester. I should be doing my best work for some company now.

By citing oneself as a loss to the professional, one is discursively positioned firmly within this wider milieu. In these various ways, the ideals of the profession in which they worked informed people's articulations of both, their positions and descriptions 
of what prompted them to speak up. Ted, Lauren, Edward and many others drew on professional ideals to articulate 'who they really are'.

\section{Outsider}

Many people represented themselves as having been an 'outsider' within their organization and specific work group, even prior to speaking out. They described how this gave them a different perspective on organizational practices including corrupt ones. In most cases, people were relatively new arrivals to their position when they spoke out, which meant that it had been necessary to ask a lot of questions:

I asked a lot of questions because I was the newcomer, and I wanted to find out how the place worked. And when I ultimately learned the answers, I thought, 'Well, it can't work this way. This is against the law, so I tried to fix it.' So, it was all quite innocent from my [side] ... (Edward)

Others cited their training and background as having been different to others in their organization: Anita, who spoke out about corruption at the United Nations was educated at an 'elite' law school unlike many of her colleagues while Ted was somewhat of an anomaly in his private sector contracting firm due to his military background. Others including Tom, another financial services whistleblower, described experiencing frequent changes of environment and schools in their youth (Table 2). In addition to having been different as a result of training or experience or life trajectories, thus seeing things in a different way and perhaps more easily spotting irregularities and unethical practices, this outsider status also suggests that they had not yet been inculcated into the norms of their specific group. A strong sense of group cohesion and loyalty is one of the biggest obstacles to speaking out (Heffernan, 2011; Janis, 1972). 


\section{Loyal employee}

Even where they described themselves as outsiders, for many a significant sense of organizational loyalty marked people's articulated subjectivities. This manifested in a number of ways: people espoused a deep commitment to improving their organization, and noted that this was what prompted disclosures about perceived wrongdoing. Edward for example describes a passion to 'defend and protect' his organization. It is, he notes:

[...] the people who are most loyal [that whistleblow] and say, 'Look, we want to preserve, protect, and defend the reputation of the place, and we don't want you to compromise the reputation. We think we can build a better company'.

He is among this group:

My primary objective in doing what I did was-you know, I'm sort of a performance-improvement architect. That's what I do for a living.

Within this, it is clear that his sense of self is tied up in how the organization is perceived, both by himself but also by others.

A second aspect of organizational loyalty emerged when people espoused positions of 'believer' in their organization's willingness to correct the wrongdoing they had seen. They presented themselves as having had faith that, once the organization learned about the wrongdoing, it would act. Returning to Lauren, after she had been dismissed for speaking up about the corruption she witnessed, her company's subsequent merger with a larger bank gave her hope. She described her belief that the new management would listen to her complaints and see the extent of the wrongdoing. They would 
surely then get rid of the people that had facilitated the systematic mortgage fraud she witnessed, re-hire her, and 'fix everything'.

I thought that they wouldn't dare you know, do anything with [the new bank] ... I just thought, '[the new bank] is here, they can't do this stuff anymore'. Lauren explained how she clung to that faith and how difficult it was to 'accept' the corruption in her company. She later learned that the new management were not only aware of the fraud, but were happy to let it continue.

Four years and a gazillion depositions later I learned that [they] just embraced that whole thing. I mean, they were already having to stave off the regulators for stuff that they were doing.

It was, she reflected, a case of 'rose-colored glasses':

I thought they were you know, some kind of knight in shining armor and it turned out they were you know ... (voice breaks)

Ted also spoke about the difficulty of accepting the layers of systemic corruption, the silencing of those who oppose it, and in his case, the UK government's long-lasting complicity (Table 2). Eric, a senior risk executive at a well-known UK bank who highlighted a toxic sales culture before being dismissed for doing so, described a similar faith in his organization. He didn't realize the risk he encountered by speaking out, he notes:

Maybe I was good at all other forms of risk management except for risk management of my own personal circumstances. I felt very strongly that if I was able to demonstrate through evidence, through the rigorous audits that we were carrying out, that things were going wrong, that I would be listened to. 
Even if I wasn't listened to by the executive, that I would be listened to by the non-executives, and also the [regulator].

As do others, Lauren and Eric constructed themselves as having been loyal to their organization in the past, an earlier position of faith that was based on flawed assumptions. Many discussed how they had been "too naïve" prior to whistleblowing, wrongly believing that their disclosures would be welcomed and treated in the spirit of improving the organization.

Finally, it appears that this portrayed position of loyal subject involves significant emotional investment. This is evident from the excerpts above, and further with UN whistleblower Anita, who likened her position in the organization to one within a love relationship:

See, the point... is that I was bound and determined to work at the [organization] because I believed in its mission on paper. You know how when a woman gets involved with a man and, you know, refuses to see that person for the way they are, they've fallen in love with their idea of that person? That was my relationship with [organization].

Claire who spoke out about patient abuse in the Irish care service, echoed this sense:

I was so disappointed because ...I was so looking forward. I had done my Masters [dissertation] on this organization. I thought these were just, like, my heroes.

Many respondents positioned themselves as having felt passionately about the organization for which they worked, noting that this fuelled their faith that the wrongdoing would be addressed. Overall therefore, a self-positioning of having been, 
in the past, a loyal organizational subject, invested in an organizational ideal, was clear throughout our interviews.

\section{'Involuntary' discloser}

Even as people cited loyalty, or professional idealism, as prompting their disclosures, they frequently described themselves as involuntarily compelled to do so: as having had 'no other choice'. George, an audit professional, discovered that ordinary people who had invested pensions in his bank would not receive their due after a merger. He recalled feeling that he had no option but to blow the whistle, it 'never occured to him' to do otherwise:

In my experiences, whistle blowers are people who make a moral choice and it probably never occurs to them to make any other choice because this is the right thing to do and therefore I will do it.

Gary, who unearthed his bank's role in supporting money laundering on the part of international drug lords, discussed this compulsion, describing it as 'instinctive':

Sometimes you do things you don't want to do; you just instinctively do what you're doing. If you think about it ... well, if you really analyzed it, you wouldn't necessarily do it. Actually, I can't sit in front of people and hold myself out to be some kind of super moral crusader. I don't see myself as that.

Gary felt that he cannot be considered heroic, because he was simply compelled to speak up and, like George, was unable to act differently. This echoes Claire's recollection of an irresistible need to speak up, not least because of the feelings of guilt she anticipated, if she stayed silent about the abuse of mental health patients she had witnessed: 
I would have paid another price if I had kept my mouth quiet. That's the point. I would have had to pay a price in a different sense.

As with other participants, Claire, Gary and George presented themselves as involuntary subjects of disclosure, compelled to speak out in the face of wrongdoing. They constructed themselves as having faced a 'choiceless choice' (Alford, 2007, see also Alford, 2001; Contu, 2014; de Maria, 2008; Scheuerman, 2014), indicating a shift from the prior position of a believer in organizational probity, and a loyal employee.

\section{Discussion}

Our data explored the ways in which whistleblower subjectivities were constructed in relation to their organizations, in the interview setting. As both Butler (2004) and Foucault (2001) note, to give an account of oneself in such a way is always to take a risk, referring to something that is never self-identical at a given point in time (Loizidou, 2007, p. 72). In the above we see the complex and sometimes conflicted nature of whistleblower subjectivity and the various positions comprising it. We draw upon our analysis of the data to propose a different conception of whistleblower subjectivity, focusing on the meaning of risk and the reinvention of the whistleblower as a truth-telling subject, in order to re-theorize this concept through passionate attachments to organizational and social norms and values.

\section{Whistleblowing as self-constitution}

Recent research into organizational whistleblowers depicts people's 'selfconstitutions' as parrhesiastic subjects. These comprise ideas of having attempted to instigate change by speaking up from a relatively low status about what one feels to 
be true and right, of being formed by the experience and emerging anew as a 'subject of truth-telling'. This construction enables the whistleblower to be 'as he (sic) ought to be and wishes to be' (Foucault, 2005, p. 318-9). Certainly, we found this to be the case in our study, with people compelled to adopt such a position. Examining this in more depth we encountered fractured, diverse subjectivities whose aspects ranged from loyal employee to involuntary discloser, for example. Whistleblowers often described themselves as simply 'doing their job' rather than performing a heroic deed. In this way, we offer an in-depth empirical account of whistleblower subjectivity as a complex and multiple phenomenon, with people moving back and forth between positions.

However, in doing so, our in-depth study yielded further insights into the constitution of whistleblower subjectivity that both build upon but also challenge existing understandings of this topic. These relate both to the risk involved but also the narrative of self-reinvention inherent to the transitionary experiences depicted. Authors describe the parrhesiastic whistleblower as adopting a position of independence, having engaged in ethical truth-telling as 'an action which is [both] risky and free' (Weiskopf \& Willmott 2013, p. 471). Indeed, from the outside, it is easy to imagine the free moral whistleblower who risks everything to speak out, but our empirically-driven analysis suggests that the situation is more complex. 
Risk

Scholars depict whistleblowers as fully aware of, and deliberately taking, risks in speaking out, moreover noting that embracing the threat of 'costly consequences' including risks to their livelihood, is an 'an essential characteristic' of of the position of parrhesiastic truth-teller (Weiskopf \& Tobias-Miersch, 2016, p. 651, see also Andrade, 2015; Mansbach, 2011; Weiskopf \& Willmott, 2013). Examining their accounts, it is true that most of our participants do appear to construct themselves as subjects who have 'risked everything' in speaking out against corruption in their organizations. However, it is not clear that this construction involves making a clear and fully-conscious decision to do so, at any specific point. In people's articulated self-constitutions, rather than risk-takers, we find professional idealists and loyal organizational adherents. We find people describing a lack of awareness of the danger they courted and the consequences of disclosing. In hindsight, they note that their actions were indeed dangerous to themselves but this was not foreseen. Rather the dangers appeared to unfold, and escalate, over an extended period of time (see also Martin \& Rifkin, 2004; Rothschild, 2013, p. 659). Our respondents describe how their trust in their organization and belief that it would take action rather than dismiss their disclosures and shun them, played an important role in their decisions to speak up. The idea of the truth-teller subject who is fully aware of what is to come, and speaks out regardless, appears unfounded in relation to these accounts. Instead we find misplaced faith in the ideals of the profession-assuming that others would also subscribe to these and be similarly shocked at clear transgressions - but also in ideals of the organization, when people discuss their faith that senior management would 
address the wrongdoing once it became apparent. These whistleblower subjectivities were intertwined with professional and organizational attachments; people describe how they expected to be listened to and perhaps praised for this service. This points to the value of in-depth empirical study of whistleblowers; while people in this position might 'look like' extreme risk-takers from the outside, this may not be the case. While we do not deny the risk and courage involved in speaking up (in fact, our experience with whistleblowers was truly humbling and turned us to committed supporters of their cause), the findings presented in this study show how people account for themselves as having never imagined they would risk their jobs and wellbeing, face divorce or lose their friends when they spoke up against wrongdoing; rather than premeditated risks these were unforeseen side-effects.

\section{Reinvention}

Scholarly conceptions of the whistleblowing subject as a free and autonomous individual persist (Contu, 2014). This subject is painted as one who steps outside of their institutional role and frees themselves from the norms they have previously embodied (Mansbach, 2009; Weiskopf \& Tobias-Miersch, 2016). Weiskopf \& Willmott (2013) cite Foucault in describing the "self-possession and selfsovereignty" of the parrhesiastic whistleblower, which enables him or her to overcome obstacles, such as fear and co-option by other forces. The whistleblower effectively "invents" him/herself as a responsible self in practices of decision making [...] opening up historically sedimented identities' (ibid. p. 475). This idea of freely 'reinventing' oneself is echoed by others (Weiskopf \& Tobias-Miersch, 2016), who 
invoke a radical break from the organization. Alford's (2007) well-known depiction of the whistleblowing act as a compulsion to be free, is followed up by Weiskopf and Tobias-Miersch who describe how Strack came to be defined and to define himself as a whistleblower, which lead to 'not only to a dis-identification with a given organizational identity, but also to a counter-identification with alternative discourses and to the affirmation of a new identity in which notions of public interest become central' (2016, p. 661).

In the case of our study we saw various instances of such 'self-constitution as an ethical subject', whereby people appeared to engage in a reinvention that relinquished previous ties to dominant forms of power including their organizations. Was this however depicted as the act of freedom that others suggest? From our data, it appears not. While people such as Gary, Eric and Lauren espoused cynical and free subject positions, when juxtaposed against the remainder of their complex articulations it appears that this freedom was somewhat constituted by the organization, as we elaborate next.

\section{Whistleblowers, passion and organization}

For participants, the organization remained a deeply-constitutive aspect of their emergent subjectivity as whistleblower. This connection was clear in the discursive positions people adopted, but crucially it was evident in the passionate, desiring attachments to aspects of organization and profession that marked their selfconstructions, and this was apparent when whistleblowers shared their experiences. For example, Lauren's voice breaks as she recalls the faith she used to have in her 
bank. Moreover, at the outset of the interview, occurring some seven years after her firing, she notes how: 'it still gives me so much anxiety...in reliving it'; she has not moved on. Anita describes herself as having been in love with her organization, while Claire's admiration for her 'hero' managers remains. Edward described a passion for 'preserving, protecting and defending' his organization. Perhaps more powerfully, a deep attachment to profession also survives to the present-day articulations of what it is to whistleblow, with Lauren evoking a 'love' for fraud, Edward describing a desire to be 'doing his best work' and Eric presenting himself as a true subject of (traditional) banking values. Ostensibly moved on, participants appear to be connected in a deeper way to the entities that have effectively cast them out and caused them pain; their former workplaces and their former professions.

Emerging from the data is a picture of whistleblowers who are 'passionately invested' in organizational and professional subject positions, despite acknowledging the pain (Butler, 1997) that these have caused them in the past and continue to do so today. The ties are not easily shaken. Even as Lauren for example attempts to invoke an independence from her former workplace, these efforts break down in emotive utterances. The values of the military ethos of service, loyalty and trust continued to guide Ted's actions when he tried to publicize his case widely in the media and through the whistleblowers organization he founded and led. Despite having been let down by the Ministry of Defence, the very organization that had instilled them, these values persisted. 
It appears that aspects of profession and organization that whistleblowers end up denouncing are more difficult to cast off than we assume. As Butler notes, the emergence of the subject in social life is inextricably intertwined with desires for recognition in relation to dominant discourses: as social subjects, we are passionately attached to achieving this acknowledgement within the terms of powerful norms that constitute us socially. Indeed others have explored how such attachments to organization can persist in a range of settings (Riach et al., 2016), from NGOs (Kenny, 2010) to health care (Fotaki, 2014). Here it appears that whistleblowing subjects are no different; desires for organizational and professional recognition persist.

\section{Theoretical implications}

Returning to literature on organizational whistleblowing therefore, we propose a different conception of whistleblower subjectivity: rather than subjects of risk, and free reinvention, we find individuals who remain passionately attached to organizational and professional norms and values even where they cause them hurt. This contributes to existing understandings in a number of ways.

Studies portray the reinvention of the whistleblower self as, on the one hand, influenced by societal norms; the parrhesiast's subjectivity is 'formed and shaped, yet not determined, by the discursive context in which it emerges and by the normative frame that governs it', as noted above (Weiskopf \& Tobias-Miersch, 2016, p. 648, see also Weiskopf \& Willmott, 2013). More often, however, this 're-identification' tends to be described as somewhat free of norms, driven only by one's own 'calling' or 
desire (Contu, 2014). Yet, doing so in a simplistic manner based on secondary accounts or high-level abstract theorizing risks glorifying such practice and overlooking the ways in which whistleblowing can be influenced by a sense of organizational and professional duty. This approach therefore tends to ignore the complex and nuanced ways in which subjects, and researchers, are deeply embedded in the organizations that are an important presence in our lives. For this reason, organizational whistleblowers are arguably different to the kinds of parrhesiastic subjects appearing in other contexts who might find themselves less attached, freer and more likely to risk all.

Others note the intertwining of parrhesiastic practice and organization, finding that the boundary between organization and whistleblower-parrhesiast can be somewhat blurred. Andrade (2015) for example uses critical complexity theory to argue that 'the identities of the corporation and its corporate members including the whistleblowerparrhesiastes, are "co-terminous $[\ldots]$ the whistleblower is firmly $[\ldots]$ fundamentally part of the organization' (p. 321). The whistleblower is an essential part of the organization, constitutive to it (see also Alford, 2001). We turn this on its head, arguing that the organization is deeply embedded within the whistleblower-self, just as the reverse is true. In addition, scholars have referred to the influences of various forms of 'moral authority' in acts of whistleblowing (see for example Weiskopf \& Tobias-Miersch, 2016), but tend not to elaborate upon the nature of this attachment. Here we propose that framing the ongoing constitution of subjectivity on the part of whistleblowers through a lens that draws on Butler but also Foucault, provides a 
valuable contribution. It explains how, from the outside, whistleblowers may appear to be free, but insidious forms of authority remain.

Overall this suggests that perhaps the 'rationality of whistleblowing' (Contu, 2014, p. 403) is not singular, or at least not as singular as might have been thought, but rather is founded in complex psychic structures of recognition, of which the organization and the professional norms it is meant to embody are key. The interpretation of parrhesia through the Foucauldian lens that most organizational scholars working on whistleblowers' subjectivity seem to adopt, is a romantic notion, and it is tempting to apply this to organizational whistleblowers. Rather than a fearless risk-taker who takes a sudden leap forward into an unknown future and re-invents herself accordingly, here we see a faithful organizational subject, embedded in affective attachments to the organization itself and the ideal it represents, even years later. Put differently, without diminishing their service to society, or undermining their courage and resolve, what sets apart the whistleblower from other employees is the very act of speaking up and not his or her superhuman qualities.

Furthermore, we acknowledge that people's accounts were co-constructions in which they were compelled to speak from the position of 'whistleblower' when narrating their experiences. The affects and feelings that emerged were thus a result of this interaction, and this was not only on the side of the interviewee. Indeed, as researchers we each felt moved and affected on numerous occasions and despite attempts to stay in the neutral position of the interviewer, we were drawn into the affective atmosphere arising during the conversations, responding to the articulations 
of our interlocutors. It was for example difficult not to share people's incredulity at the depth of corruption occurring in well-known organizations (ranging from the NHS to global banks), and the lengths to which organizations could go in order to retaliate. Reflecting on our role in these interactions, we were surprised at the strength of the affective 'pull' this had on us. This suggests that we too found it difficult to accept the depth of wrongdoing, indicating our inadvertent interpellation by organizational power, but it also highlights the dynamics underpinning our empathy with courageous whistleblowers who generously shared their painful experiences with us even beyond the duration of our various projects.

These observations have implications for empirical research into whistleblowing; an attentiveness to passionate attachments can help us to begin to apprehend the 'fundamental sociality of embodied life' (Butler, 2004, p. 22). Displays of emotion and affect by researchers as well as the research subject occur in the relational space that is created between them, and these can help us understand the role of affect in subjection to power (Butler, 2004, p. 235). Having listened to these excruciating and painful accounts we could not help experiencing our respondents' feelings albeit vicariously and reflecting upon our own attachments in respective situations. These attachments thus pertain both to those who engage in whistleblowing and those who research them. 


\section{Practical implications}

This study challenges existing interpretations of organizational whistleblowers while building upon them to develop a more nuanced understanding of such experiences in action. The importance of this is not simply theoretical however. Conceiving of the whistleblower subject as courageous risk-taker who is somewhat free and autonomous from the influence of others and the social invokes a whistleblower-self who is both super-human in their autonomy, and unrealistically fearless in the face of risk. It does not relate to the subjects we encountered (see also Brown, 2017). Most whistleblowers are not particularly unusual; they are 'ordinary people' albeit courageous ones (Contu, 2014; Mansbach, 2009). It is not easy to empathize with extraordinary, 'super-human' heroes. Nor is it easy to see them as vulnerable and deserving of help. Currently society provides little if any assistance for those whose careers, families and incomes are destroyed in the 'afterlife' of whistleblowing (Smith, 2014). Even if they are cherished and their courage is admired by the public, few realize the true cost of whistleblowing and the need for help. To conceive of the whistleblower-parrhesiastes as fearless and self-driven is to promote the idea that supports to assist people in speaking out, such as legal protections and organizational speak-up systems are unnecessary, as if parrhesia will simply emerge spontaneously because of the 'exceptional courage' of those who engage in it (Brown, 2017). To portray them as such is therefore to deter would-be resisters. 


\section{Conclusion}

We contribute to studies of speaking out in organizations by offering a theoretical framing that highlights the passionate nature of whistleblower subject constructions that are entangled in discourses of professionalism but also in attachments to the organization that has rejected and retaliated against them. To appreciate the challenging nature of this position an attentiveness to these organizational attachments is essential. Applying a somewhat heroic label to the whistleblower, in a simplistic manner, can undermine the original disclosure and reduce support for the ordinary people who engage in such actions. Our proposed conception of whistleblower subjectivity thus represents a fruitful development of this important theory within organization studies.

\section{References}

Alford, C. F. (2001). Whistleblowers: Broken lives and organizational power. Ithaca: Cornell University Press.

Alford, F. (2007). The whistleblower's 'choiceless choice'. Social Research: An International Quarterly, 74, 223-248.

Alvesson, M. \& Skoldberg, K. (2009). Reflexive methodology: New vistas for qualitative research. London: Sage.

Andrade, J.A. (2015). Reconceptualizing whistleblowing in a complex world. Journal of Business Ethics, 128, 321-335.

Brown, A. J. (2017). Whistleblowers as heroes: Fostering quiet heroism in place of the heroic whistleblower stereotype. In Allison, S. ,Goethals, G. \& Kramer, R. (Eds), Handbook of heroism and heroic leadership. London: Routledge, 356-376.

Butler, J. (1990). Gender Trouble. London: Routledge. 
Butler, J. (1997). The psychic life of power: Theories in subjection. London: Routledge.

Butler, J. (2004). Undoing gender. New York: Routledge.

Charmaz, K. (2006). Constructing grounded theory: A practical guide through qualitative data analysis. London: Sage.

Contu, A. (2014). Rationality and relationality in the process of whistleblowing: Recasting whistleblowing through readings of Antigone. Journal of Management Inquiry, 23, 393-406.

De George, R.T. (2010). Business Ethics (7th ed.). New York: Prentice Hall.

De Maria, W. (2008). Whistleblowers and organizational protesters: Crossing imaginary borders. Current Sociology, 56, 865-883.

Driver, M. (2012). The lack of power or the power of lack in leadership as a discursively constructed identity. Organization Studies, 298-318.

Ellis, C. (2007). Telling secrets, revealing lives: Relational ethics in research with intimate others. Qualitative Inquiry, 13, 3-19.

Fotaki, M., Kenny, K. \& Vachhani, S. (2017). Thinking critically about affect in organization studies: Why it matters. (Editorial) Organization, 24(1), 3-17.

Fotaki, M. and Harding, N. (2013). Lacan and sexual difference in organization and management theory: Towards a hysterical academy? Organization, 20, 153-172.

Fotaki, M. (2014). Can consumer choice replace trust in the National Health Service in England? Towards developing an affective psychosocial conception of trust in health care. Sociology of Health \& Illness, 36(8), 1276-1294.

Fotaki, M. (2009). Maintaining the illusion of a free health service in post-socialism: A Lacanian analysis of transition from planned to market economy. Journal of Organizational Change Management, 22(2), 141-158.

Fotaki, M. (2010). Why do public policies fail so often? Exploring health policy making as an imaginary/symbolic construction. Organization, 17(6), 703-720.

Foucault, M. (2001). Fearless Speech. Los Angeles: Semiotext(e).

Foucault, M. (2005) The Hermeneutics of the Subject: Lectures at the Collège de France, 1981-1982, (ed.) F. Gros, (trans.) G. Burchell. Houndmills: Palgrave Macmillan. 
Foucault, M. (2010). The government of self and others: Lectures at the Collège de France 1982-83. Basingstoke: Palgrave Macmillan.

Gilmore, S. \& Kenny, K. (2015). Work-worlds colliding: Self-reflexivity, power and emotion in organizational ethnography. Human Relations, 68, 55-87.

Grant, C. (2002). Whistleblowers: Saints of secular culture. Journal of Business Ethics, 39, 391-399.

Hall, S. (2000). Who needs identity? In Du Gay, P., Evans, J. \& Redman, P. (Eds), Identity: a reader. London: Sage.

Harding, N. (2008). The 'I', the 'me' and the 'you know': Identifying identities in organizations. Qualitative Research in Organizations and Management, 3, 42-58.

Heffernan, M. (2011). Willful blindness - Why we ignore the obvious at our peril. Walker \& Company.

Hersh, M. A. (2002). Whistleblowers-heroes or traitors?: Individual and collective responsibility for ethical behaviour. Annual Reviews in Control, 26(2), 243-262.

Hook, D. (2007). Foucault, psychology and the analytics of power. Hampshire: Palgrave.

Jack, G. (2004). On speech, critique and protection. Ephemera, 4, 121-134.

Jameson, F. (1984). Postmodernism, or the cultural logic of late capitalism. New Left Review, 146, 59-92.

Janis, I. L. (1972). Victims of groupthink: a psychological study of foreign-policy decisions and fiascoes. Oxford, England: Houghton Mifflin.

Jones, C., Parker, M. \& ten Bos, R. (2005). For Business Ethics. London: Routledge. Kenny, K. M. (2010). Beyond ourselves: Passion and the dark side of identification in an ethical organization. Human Relations, 63(6), 857-873.

Kenny, K., \& Gilmore, S. (2014). From research reflexivity to research affectivity: ethnographic research in organizations. In K. Kenny, \& M. Fotaki (Eds.), The psychosocial and organization studies: affect at work (pp. 158-182). Basingstoke: Palgrave Macmillan. 
Kenny, K., Fotaki, M. \& Scriver, S. (2018). Mental health as a weapon: Whistleblower retaliation and normative violence. Journal of Business Ethics https:// link.springer.com/article/10.1007/s10551-018-3868-4

Komporozos-Athanasiou, A., Thompson, M. \& Fotaki, M. (2018). Performing accountability in health research. Human Relations, 71(9), 1264-1287.

Kenny, K. (2017) Censored: Impossible speech and financial sector whistleblowers. Human Relations [DOI: 10.1177/0018726717733311]

Mansbach, A. (2009). Keeping democracy vibrant: whistleblowing as truth-telling in the workplace. Constellations: An international journal of critical and democratic theory, 16, 363-376.

Mansbach, A. (2011). Whistleblowing as fearless speech: The radical democratic effects of late modern parrhesia. In D. Lewis \& W. Vandekerckhove (Eds.), Whistleblowing and Democratic Values (pp. 12-26). Middlesex: The International Whistleblowing Research Network.

Martin, B. \& Rifkin, W. (2004). The dynamics of employee dissent: whistleblower and organizational jiu-jitsu, Public Organization Review: A Global Journal, 4, 221-238.

Miceli, M. P., Near, J.P. \& Dworkin, T.M. (2008). Whistleblowing in organizations, London: Routledge.

Munro, I. (2017). Whistle-blowing and the politics of truth: Mobilizing 'truth games' in the WikiLeaks case. Human Relations, 70, 5, 519-543.

Parker, I. (2005). Lacanian discourse analysis in psychology: Seven theoretical elements. Theory and Psychology, 15, 163-182.

Perry, N. (1998). Indecent exposure: Theorizing whistleblowing. Organization Studies, 19, 235-257.

Pullen, A. (2006). Gendering the research self: Social practice and corporeal multiplicity in the writing of organizational research. Gender, Work and Organization, 13, 277-298.

Reay, T., Chreim, S., Golden-Biddle, K., Goodrick, E., Williams, B.E. (Bernie), Casebeer, A., Pablo, A. \& Hinings, C.R. (2013). Transforming new ideas into 
practice: An activity based perspective on the institutionalization of practices. Journal of Management Studies, 50, 963-990.

Riach, K., Rumens, N. \& Tyler, M. (2014). Un/doing chrononormativity: Negotiating ageing, gender and sexuality in organizational life. Organization Studies, 35, 16771698.

Riach, K., Rumens, N., \& Tyler, M. (2016). Towards a Butlerian methodology: Undoing organizational performativity through anti-narrative research. Human Relations, 69(11), 2069-2089.

Rothschild, J. (2013). The fate of whistleblowers in nonprofit organizations, Nonprofit and Voluntary Sector Quarterly, 42, 886-901.

Scheuerman, W. E. (2014). Whistleblowing as civil disobedience: The case of Edward Snowden. Philosophy and Social Criticism, 40, 609-628.

Smith, A. (2014). There were hundreds of us crying out for help: The afterlife of the whistleblower. Guardian, 22nd November 2014.

Vandekerckhove, W. (2006). Whistleblowing and organizational social responsibility: A global assessment. Ashgate Publishing.

Vandekerckhove, W. \& Langenberg, S. (2012). Can we organize courage? Implications from Foucault's parrhesia. Electronic Journal of Business Ethics and Organizational Studies, 17(2), 35-44.

Weiskopf, R. \& Tobias-Miersch, Y. (2016). Whistleblowing, parrhesia and the contestation of truth in the workplace. Organization Studies, 37, 1621-1640.

Weiskopf, R. \& Willmott, H. (2013). Ethics as critical practice: The Pentagon papers, deciding responsibly, truth-telling, and the unsettling of organizational morality, Organization Studies, 34, 469-493. 
Table 1: Empirical Research

\begin{tabular}{|l|l|l|l|}
\hline Project and Funding Organization & $\begin{array}{l}\text { No. of } \\
\text { whistleblow } \\
\text { ers } \\
\text { interviewed } \\
*\end{array}$ & $\begin{array}{l}\text { Employment } \\
\text { sectors }\end{array}$ & $\begin{array}{l}\text { Dates interviews } \\
\text { were conducted }\end{array}$ \\
\hline $\begin{array}{l}\text { JE Safra Centre for Ethics/ } \\
\text { Millennium Fund }\end{array}$ & 15 & $\begin{array}{l}\text { Financial } \\
\text { services } \\
\text { including sales, } \\
\text { compliance, and } \\
\text { audit functions. }\end{array}$ & $\begin{array}{l}\text { April 2011- } \\
\text { December 2012 }\end{array}$ \\
\hline $\begin{array}{l}\text { 2. What makes whistleblowing } \\
\text { possible across different industries? }\end{array}$ & $22 * *$ & $\begin{array}{l}\text { Military, Leisure } \\
\text { services, } \\
\text { Banking, Social } \\
\text { work, } \\
\text { International } \\
\text { Development, } \\
\text { Health. }\end{array}$ & $\begin{array}{l}\text { December 2013- } \\
\text { February 2015 }\end{array}$ \\
\hline
\end{tabular}

* For each project, professional experts on the topic of whistleblowing were also interviewed, including industry regulators and specialist lawyers (Project 1), and psychiatrists specializing in whistleblowing, regulators and advisory group leaders (Project 2).

** Seven participants who had taken part in Project 1 were re-interviewed for Project 2.

TABLE 2 CODING AND THEMES 


\begin{tabular}{|c|c|c|c|}
\hline $\begin{array}{l}\text { Primary } \\
\text { theme: } \\
\text { Espoused } \\
\text { organizati } \\
\text { onal } \\
\text { subject } \\
\text { position }\end{array}$ & $\begin{array}{l}\text { Discursiv } \\
\text { e } \\
\text { positionin } \\
\text { g of the } \\
\text { "I" in the } \\
\text { interview } \\
\text { interactio } \\
n\end{array}$ & $\begin{array}{l}\text { Sub-theme: } \\
\text { Constitutive aspects } \\
\text { of the espoused } \\
\text { organizational } \\
\text { subject position }\end{array}$ & Excerpts from data \\
\hline $\begin{array}{l}\text { Profession } \\
\text { al }\end{array}$ & $\begin{array}{l}\text { The "I" is } \\
\text { posited as } \\
\text { having } \\
\text { been } \\
\text { committed } \\
\text { to the } \\
\text { ideals of } \\
\text { the } \\
\text { profession } \\
\text {. }\end{array}$ & $\begin{array}{l}\text { The subject is } \\
\text { posited as an } \\
\text { adherent of } \\
\text { specified rules and } \\
\text { practices including } \\
\text { in relation to } \\
\text { wrongdoing, and } \\
\text { thus espouses shock } \\
\text { when it is prevalent. } \\
\text { This commitment } \\
\text { prompted action } \\
\text { when perceived } \\
\text { wrongdoing } \\
\text { threatened the } \\
\text { subject position. }\end{array}$ & $\begin{array}{l}\text { SFO allowed the company to do an internal } \\
\text { investigation and they got in a company of } \\
\text { auditors called [Company A]. I wrote to } \\
\text { the director of the SFO and said "are you } \\
\text { aware that the previous auditors of the } \\
\text { company were [Company A] before } \\
\text { [current auditors]? Are you aware that we } \\
\text { have now traced the payments back over } \\
30 \text { years to when Company A were the } \\
\text { auditors during that period? And therefore } \\
\text { do you think that the conclusions you are } \\
\text { going to be given by the so-called } \\
\text { independent investigation are going to be } \\
\text { truly independent and truly objective } \\
\text { because, effectively, they will be rubber } \\
\text { stamping their own mis-auditing over the } \\
\text { previous years. [Richard] } \\
\text { The essence of a bank is prudence. You } \\
\text { have a fiduciary duty to your customer... } \\
\text { Taking bets with other people's money } \\
\text { doesn't fit within the definition of banking. } \\
\text { A firm must act with integrity; a firm must } \\
\text { act with due skill, care and diligence. A } \\
\text { firm must have adequate systems and } \\
\text { controls... A firm must pay due regard to } \\
\text { the interests of its customers and treat them } \\
\text { fairly [Edward] }\end{array}$ \\
\hline & & $\begin{array}{l}\text { Committed to the } \\
\text { 'old' (pre-1980s) } \\
\text { values of banking, } \\
\text { its traditional social } \\
\text { and community } \\
\text { value. }\end{array}$ & $\begin{array}{l}\text { When I was a kid, bankers were like the } \\
\text { paragons of ethics, you know, because it } \\
\text { was all community banks. They didn't } \\
\text { have this-banks couldn't cut across state } \\
\text { lines then in the 50s and 60s. A banker was } \\
\text { your friend. And now, the bankers are just } \\
\text { trying to rip you off. [Eddie] }\end{array}$ \\
\hline
\end{tabular}




\begin{tabular}{|c|c|c|c|}
\hline & & $\begin{array}{l}\text { Subjects are } \\
\text { described as a loss } \\
\text { to the profession, if } \\
\text { they have been } \\
\text { forced to resign or } \\
\text { have been } \\
\text { dismissed as a } \\
\text { result of disclosure. } \\
\text { This is due to the } \\
\text { loss of their skills } \\
\text { and commitment. }\end{array}$ & $\begin{array}{l}\text { To be a successful money-laundering } \\
\text { reporting officer (MLRO) these days, you } \\
\text { have to know which questions not to ask... } \\
\text { Banks don't want MLROs with any skills, } \\
\text { experience, or the independent knowledge } \\
\text { to be able to stand up to the commercial } \\
\text { people and say, "You can't do that!" [Gary] }\end{array}$ \\
\hline Outsider & $\begin{array}{l}\text { Subject is } \\
\text { constitute } \\
\text { d as one } \\
\text { who was } \\
\text { an } \\
\text { 'outsider' } \\
\text { even prior } \\
\text { to } \\
\text { speaking } \\
\text { out }\end{array}$ & $\begin{array}{l}\text { Subject is new to } \\
\text { the organization, or } \\
\text { comes from a } \\
\text { different } \\
\text { background. } \\
\text { Therefore they } \\
\text { espouse a position } \\
\text { free of cultural } \\
\text { norms pertaining to } \\
\text { the new context, but } \\
\text { also a new way of } \\
\text { looking at a } \\
\text { problem. }\end{array}$ & $\begin{array}{l}\text { [I was] lucky enough to have had an elite } \\
\text { training. I went to Yale Law School so that } \\
\text { gave me - I wouldn't say an arrogance - } \\
\text { but that gave me a feeling of entitlement. } \\
\text { [Anita] } \\
\text { Well, I come from a military background. } \\
\text { Okay. The reason people fight in a trench } \\
\text { on the battlefield is because I protect you } \\
\text { and you protect me and we have a common } \\
\text { understanding about "I will not betray you; } \\
\text { I will not run away; I will stand and look } \\
\text { after you; and you will do the same for } \\
\text { me." ...Beneath that is an understanding of } \\
\text { trust. ....And when you betray that trust } \\
\text { you undermine the whole structure of } \\
\text { society. } \\
\text {...I went to the MoD here in England and I } \\
\text { wrote a paper, a proper staff paper, a } \\
\text { military paper, not an academic } \\
\text { paper...And I was a colonel in the army, a } \\
\text { staff officer in the MoD, so I know how to } \\
\text { write a military report. I took it to the MoD } \\
\text { and said "read that and do something about } \\
\text { it". [Ted] }\end{array}$ \\
\hline
\end{tabular}




\begin{tabular}{|c|c|c|c|}
\hline \multirow[t]{2}{*}{$\begin{array}{l}\text { Loyal } \\
\text { employee }\end{array}$} & $\begin{array}{l}\text { Subject is } \\
\text { positioned } \\
\text { as very } \\
\text { loyal to } \\
\text { their } \\
\text { organizati } \\
\text { on. }\end{array}$ & $\begin{array}{l}\text { Committed to } \\
\text { improvement: } \\
\text { Subject is described } \\
\text { as speaking up from } \\
\text { a desire to right the } \\
\text { wrongdoing and } \\
\text { improve their } \\
\text { organization. }\end{array}$ & $\begin{array}{l}\text { And I was out there in their face, nicely, } \\
\text { gently. It's my job to tell people where } \\
\text { there's a better way to do it; a higher } \\
\text { quality way; a lower cost way; a more } \\
\text { ethical way. That's my job.... my primary } \\
\text { objective was, "Hey, you guys stop doing } \\
\text { this. Start doing the antithesis. I won't say } \\
\text { anything about it. Let's just work together } \\
\text { and let's have you pursue quality, not } \\
\text { quantity" [Edward] }\end{array}$ \\
\hline & & $\begin{array}{l}\text { Believer in the } \\
\text { organization's } \\
\text { desire to correct the } \\
\text { wrongdoing: } \\
\text { Subject as faithful } \\
\text { to the idea that the } \\
\text { organization will } \\
\text { act, once they have } \\
\text { alerted it to the } \\
\text { wrongdoing. }\end{array}$ & $\begin{array}{l}\text { I gave [information about the wrongdoing] } \\
\text { to the MoD believing still at the time that } \\
\text { they would be honest in dealing with me, } \\
\text { and honest in what they were going to do } \\
\text { with the information. I still didn't believe } \\
\text { at that point in time that they knew about } \\
\text { [the corruption]... I didn't realize the MoD } \\
\text { would betray me. I didn't realize that a } \\
\text { man I'd known for } 20 \text { years who was a } \\
\text { brigadier would choose to obey the orders } \\
\text { of the MoD not be honest and open and say } \\
\text { "Ted, I'll give you a day. Get out because } \\
\text { I've got to give this up" [Ted]. } \\
\text { When I gave them the feedback I thought } \\
\text { they'd say thanks. And I thought that } \\
\text { would be it. I didn't know that [I would be } \\
\text { singled out]. [Eddie]. }\end{array}$ \\
\hline
\end{tabular}




\begin{tabular}{|c|c|c|c|}
\hline & & $\begin{array}{l}\text { Subject as } \\
\text { emotionally } \\
\text { invested in the } \\
\text { organization. }\end{array}$ & $\begin{array}{l}\text { [My whistleblowing experience] still gives } \\
\text { me so much anxiety when um.... in } \\
\text { reliving it. [Lauren] } \\
\text { [Upon realizing that his organization was } \\
\text { trying to isolate and scapegoat him]: And I } \\
\text { broke down. I cried. It happened two or } \\
\text { three times over the next week. You know, } \\
\text { the children ring up, "Hi daddy, are you all } \\
\text { right?" I remember talking to [name] my } \\
\text { oldest and saying "No, I'm not. I'm in } \\
\text { bits". And I just, again, I broke down and } \\
\text { cried. I'm not the type of person who does } \\
\text { that. And they really... they almost got me. } \\
\text { They almost got me. Psychologically they } \\
\text { almost got me. I think it had been working } \\
\text { on me for some time. But, anyway... } \\
\text { [Ted] }\end{array}$ \\
\hline $\begin{array}{l}\text { Involuntar } \\
\text { y discloser }\end{array}$ & $\begin{array}{l}\text { Compelle } \\
\text { d } \\
\text { whistleblo } \\
\text { wer: } \\
\text { Subject } \\
\text { describes } \\
\text { a 'choice- } \\
\text { less } \\
\text { choice'; a } \\
\text { compulsio } \\
\text { n to } \\
\text { speaking } \\
\text { up about } \\
\text { the } \\
\text { wrongdoi } \\
\text { ng } \\
\text { perceived. }\end{array}$ & & $\begin{array}{l}\text { Somebody had to do it... I don't want to be } \\
\text { going in twenty years' time, thirty years' } \\
\text { time, look back and wish I had done } \\
\text { something [Mary] } \\
\text { It just wasn't right... I've got a story to } \\
\text { tell... we've got to do it [Lauren] }\end{array}$ \\
\hline
\end{tabular}

